\title{
Sustainable Tourism Development and Management in the Phuket Province, Thailand
}

\author{
Thongphon Promsaka Na Sakolnakorn ${ }^{1}$, Aree Naipinit ${ }^{2} \&$ Patarapong Kroeksakul $^{3}$ \\ ${ }^{1}$ Research Center for Asia Pacific Development Studies, Faculty of Liberal Arts, Prince of Songkla University, \\ Hat Yai Campus, Songkhla, Thailand \\ ${ }^{2}$ Faculty of Management Science, Khon Kaen University, Khon Kaen, Thailand \\ ${ }^{3}$ Faculty of Environmental Culture and Ecotourism, Srinakharinwirot University, Bangkok, Thailand \\ Correspondence: Thongphon Promsaka Na Sakolnakorn, Research Center for Asia Pacific Development Studies, \\ Faculty of Liberal Arts, Prince of Songkla University, Hat Yai, Songkhla, 90112, Thailand. E-mail: \\ thongphon.p@psu.ac.th
}

Received: February 27, 2013 Accepted: April 6, 2013 Online Published: June 1, 2013

doi:10.5539/ass.v9n7p75

URL: http://dx.doi.org/10.5539/ass.v9n7p75

\begin{abstract}
This study aims to study 1) the problems and threats facing sustainable tourism management in Phuket, 2) the important factors affecting the guidelines for conservation and sustainable tourism promotion in Phuket, and 3) the policy guidelines for tourism development in Phuket. This study used both qualitative and quantitative methods, and the tools for data collection were a questionnaire (400 sample), question framework, and semi-structured interviews. From the results, the researchers identified the following problems and threats in Phuket: 1) traffic jams, 2) conservation of natural resources, 3) waste management, 4) high cost of living, 5) tax policies, and 6) labor costs. The important factors affecting the guidelines for conservation and sustainable tourism promotion in Phuket and the policy guidelines for tourism development in Phuket necessitates that government agencies involved in tourism policy focus on: 1) the necessities of daily life, 2) security and access, 3) cultural tourism management, 4) conservation of natural resources and the environment, 5) public services, 6) waste management, and 7) the public transportation system.
\end{abstract}

Keywords: public policy, guidelines, sustainable development, tourism management

\section{Introduction}

Tourism is one of the most important tools used to boost economies, promotes development by creating jobs that increase people's income, and is thus considered a key factor in development for developing countries. Therefore, tourism serves as a potential means to generate higher revenue for a country (Szivas, Riley, \& Airey, 2003). In 2009, approximately 14 million foreign tourists visited Thailand, and tourism generated 527,000 million baht (approximate $1 \mathrm{Baht}=0.03$ US\$) (Ministry of Tourism and Sports, 2010).

Phuket in southern Thailand is a major tourism destination. The Phuket Provincial Administration Organization has issued policies to increase tourism and effectively implement the tourism development plan for Phuket. The provincial administration aims to promote Phuket as a world-class center of marine tourism, which generate much revenue locally and nationally. In other words, local organizations and the federal government must support the development plan for tourism in Phuket to increase revenue from tourism. For example, the construction of Convention Centre and Exhibition (MICE) has positioned Phuket as a center of international medical service, health service, and spa health tourism and a paradise of international shopping (Shopping Paradise, OTOP Bazaar). In addition, the development plan addresses protection of Phuket's environmental, social, and physical landscapes; the restoration of natural and cultural attractions; infrastructure development; raising the services standards of tourism-related business in Phuket; the promotion of Phuket in domestic and international tourism markets; the production of employees to support tourism activities; the development of tourism human resources through the cooperation of businesses and educational institutions; the expansion of the tourism market by creating activities such as eco-tourism; the creation and development of tourism sources and a tourism network in the local community; the support of urban tourism, especially within Phuket city by increasing the value of historical attractions, such as the Sino-Portuguese building; the promotion of cultural 
tourism, including creating new tourism attractions that integrate nature and culture; the construction a tourism information center; and improvements to Phuket's security system (Piboon, 2009).

Charn (2009) identified long-term problems and threats facing tourism management in Phuket: 1) political issues-A lack of political ethics has become a serious issue in Thailand. Politicians focus only on their interests, which sparks local conflicts; 2) local and regional management-Local residents are not unified behind and do not participate in management; 3) traffic and accidents; 4) water management-Phuket's water supply is insufficient to meet the consumption demands, especially in tourist areas; 5) healthcare and waste management; 6) environmental degradation-Inappropriate land use harms the surrounding environment; 7) deterioration of local culture; and 8) competition between local businesses and international investors-Local businesses often lack the competitive advantages of international investors, such as knowledge, technology, investment funds, and business ethics. Additionally, Promsaka Na Sakolnakorn and Naipinit (2011) found seven factors that affect sustainable tourism management: 1) protection of natural resources, 2) traffic jams, 3) tax policies, 4) travel costs, 5) labor, 6) waste management, and 7) crime.

This research then raises questions about tourism management in Phuket: 1) What problems does tourism management in Phuket face? 2) What important factors affect the guidelines for sustainable tourism management? 3) What should be the policy guidelines to support and promote conservation and sustainable tourism? Based on these questions and the problems facing Phuket, research interest then emerges in identifying the results that would lead to the development of sustainable tourism, act as guidelines for the private sector, and generate revenue for the local community. This research project studies three main areas: 1) the problems and threats facing sustainable tourism management in Phuket, 2) the important factors affecting the guidelines for conservation and sustainable tourism promotion in Phuket, and 3) to study policy guidelines for tourism development in Phuket.

\section{Methodology}

To meet the stated objectives, the researchers employed a mixed-method approach.

\subsection{Problems and Threats Facing Sustainable Tourism Management in Phuket}

Qualitative data were collected through in-depth interviews. Forty-five informants, who were tourism business owners, tourists, and local residents, were placed into three groups to discuss the problems and threats facing tourism management. The researchers collected this qualitative data October 11-29, 2010. In addition, the data collected from the interviews were analyzed using the content analysis method to identify additional problems and threats.

\subsection{Important Factors Affecting the Guidelines for Conservation and Sustainable Tourism Promotion in Phuket}

After analyzing qualitative data collected in the interviews, the researchers used it to create a questionnaire to collect quantitative data about the important factors affecting the guidelines for conservation and sustainable tourism promotion in Phuket. For quantitative data collection, the participants, who were tourism business owners, tourists, and local residents, were divided into three groups. The questionnaire consisted of two parts inquiring about 1) demographic information, including sex, age, educational level, marital status, and reason for living in Phuket, and 2) opinions on sustainable tourism development and management in Phuket. The questionnaire used the Linkert scale and offered four answers: strongly agree, agree, disagree, and strongly disagree. The closed questionnaire was interpreted by dividing the question scale into a 4-point scale, as shown in Table 1.

Table 1. Significance of points

\begin{tabular}{cc}
\hline Average scores & Level of Significance \\
\hline $1.00-1.49$ & Lowest \\
$1.50-2.49$ & Low \\
$2.50-3.49$ & High \\
$3.50-4.00$ & Higher \\
\hline
\end{tabular}

To calculate the sampling size, Taro Yamane's formula (1973) was used, and a 95\% confidence level was selected for the following formula: 


$$
n=\frac{N}{1+N e^{2}}
$$

in which

$\mathrm{n}=$ sampling size

$\mathrm{N}=$ population size

$\mathrm{e}=$ level of precision of the confidence level of $95 \%$

According to the Phuket Provincial Administrative Organization (2010), Phuket had a population of 335,913 in December 2009. That year, 1,190,032 tourists traveled through the Phuket immigration office, and the province had 1,015 tourism businesses (Phuket Directory, 2011).

The population size of the study then was 1,526,960. Using Yamane's (1973) formula, the researchers calculated the sampling size as 399.89 , rounded up to 400 . Next, the researchers calculated the appropriate sampling size for each group, as presented in Table 2 .

Table 2. Sampling size for each group

\begin{tabular}{|c|c|c|c|}
\hline Group & Population & Percentage & Sampling size \\
\hline Residents & 335,913 & 22 & 88 \\
\hline Tourism enterprises & 1,015 & 1 & 4 \\
\hline Tourists & $1,190,032$ & 77 & 308 \\
\hline Total & $1,526,960$ & 100 & 400 \\
\hline
\end{tabular}

Based on those calculations, the researchers collected data from the following sampling sizes: 1) 88 local residents, 2) 4 tourism enterprises, and 3) 308 tourists.

\subsection{Quantitative Data Collection}

The researchers collected quantitative data through the following process.

\section{1) Content validity measuring}

Three experts checked the accuracy and validity of the proposed questionnaire and gave comments that guided revisions.

2) Questionnaire reliability measuring

Before official data collection, the questionnaire was tested with 30 people similar to the sampling group. The test was performed in the Krabi province in July 2011. The reliability of the results was analyzed with SPSS for Microsoft Windows, which found an alpha coefficient of 0.9032 .

3) Data collection

The researchers visited Phuket province in August 2011 to collect data. Random sampling was used in the collection conducted during August 2011.

4) Quantitative data analysis

SPSS for Windows was used to analyze data to determine the statistical relationship of this study. The analysis set a significance level at 0.05 . The researchers set the pattern of data analysis as follows.

a) A nominal scale was used for demographic information, such as sex, age, career, income, and educational level. Percentages were used in the data analysis.

b) The statistical analysis of data about opinions on the sustainable tourism development and management in Phuket used the mean, standard deviation, and Chi-Square test.

c) Factor analysis was used to group several variables from the data about the important factors affecting guidelines for conservation and sustainable tourism promotion. Variables related to each other were grouped in the same factor (Kunlaya, 2006, 7). The equation used to estimate the factors was

in which

$$
F_{j 1}=W_{j 1} X_{1}+W_{j 2} X_{2}+\cdots+W_{j p} X_{p 1}+e
$$


$\mathrm{X}_{\mathrm{j}}=$ Variables at $\mathrm{j}$

$\mathrm{W}_{\mathrm{j}}=$ Coefficient of the variable at $\mathrm{j}$

$\mathrm{e}=$ Unique factor error

\subsection{Policy Guidelines for Tourism Development in Phuket}

To study the policy guidelines for tourism development in Phuket, the researchers used a qualitative approach. Eight experts in Phuket tourism were invited to a focus group to discuss appropriate guidelines. At the beginning of the focus group discussion, the researchers presented their results about the problems and threats facing tourism management in Phuket and the important factors affecting the guidelines for conservation and sustainable tourism promotion. Next, the experts shared their opinions and discussed various topics to determine suitable guidelines for tourism development in Phuket. Data analysis was performed using descriptive analysis.

\section{Results}

\subsection{Problems and Threats Facing Sustainable Tourism Management in Phuket}

The researchers collected and analyzed data from in-depth interviews with 30 participants, obtaining the following results.

\subsubsection{Problems on Which All Participants Agreed}

1) Traffic jams: These usually occur in the morning (7:30-9 a.m.) and late afternoon (3-5:30 p.m.). Traffic jams significantly affect both residents and tourists. In addition, narrow roads were identified as a problem.

2) Destruction of natural resources: Natural resources in Phuket have been destroyed by real estate developments, such as resorts, hotels, or other tourist accommodations, and businesses, such as boxing gyms and outdoor camping.

3) Waste management and public hygiene: The growing population in Phuket has made waste management a more serious problem. Local governments have not gotten rid of waste effectively, causing bad orders and pollution.

4) High cost of living: Most participants stated that the cost of living in Phuket is higher than in other areas and neighboring countries, including Malaysia, Burma, the Lao People's Democratic Republic, Vietnam, and Cambodia.

\subsubsection{Problems Concerning Local Residents}

The study identified crime as the top concern of residents. The growth of tourism has resulted in a rise in crime, especially crime related to illegal laborers. Nighttime activities, including those related nightclubs and entertainment complex, are also sources of crime.

\subsubsection{Problems Concerning Business Owners}

1) Double taxation: Business owners in Phuket pay taxes to both the local administrative organization and the national revenue department.

2) Labor shortages: Shortages, particularly of Thai workers, have forced business owners to hire laborers from neighboring countries, including Burma and Cambodia. The study also found that Bhutanese and Nepalese laborers are commonly hired by businesses at Patong Beach. Business owners prefer international laborers over Thai workers because of lower hiring costs but still need Thai laborers, who generally possess more skills.

\subsection{Important Factors Affecting Guidelines for Conservation and Sustainable Tourism Promotion in Phuket}

The researchers analyzed data collected from the in-depth interviews and designed the questionnaire to identify which factors were considered important issues in tourism promotion in Phuket. The researchers used purposive and convenience sampling to collect data. From the collected data, the researchers grouped factors affecting the guidelines for tourism promotion in Phuket. Factor analysis was used, as presented in Table 3. 
Table 3. Analysis of factors affecting the guidelines for tourism promotion in Phuket

\begin{tabular}{|c|c|c|c|}
\hline Factor $(\mathrm{X})$ & Variables & Extraction & $\begin{array}{c}\text { Factor } \\
\text { Loading }\end{array}$ \\
\hline \multirow[b]{2}{*}{ Necessities for daily } & 23. Unique foods are desired. & 0.827 & 0.788 \\
\hline & $\begin{array}{l}\text { 15. Double taxation should be cancelled to allow businesses to } \\
\text { sell products at lower prices. }\end{array}$ & 0.827 & 0.788 \\
\hline \multirow[t]{5}{*}{ life $(\mathrm{X} 1)$} & $\begin{array}{l}\text { 16. Government agencies should control the sales price of } \\
\text { products and services, especially consumables. }\end{array}$ & 0.806 & 0.670 \\
\hline & 24. Local food is delicious. & 0.806 & 0.670 \\
\hline & $\begin{array}{l}\text { 17. Government agencies should limit and regulate } \\
\text { entertainment venues, especially nightspots, to ensure that they } \\
\text { do not violate the laws, such as those on opening times. }\end{array}$ & 0.755 & 0.726 \\
\hline & $\begin{array}{l}\text { 25. Phuket should have high standards of healthcare services } \\
\text { for tourists and residents. }\end{array}$ & 0.755 & 0.726 \\
\hline & $\begin{array}{l}\text { 20. Government agencies should proactively register } \\
\text { international laborers to solve crime problems and illegal } \\
\text { immigration. }\end{array}$ & 0.817 & 0.705 \\
\hline \multirow[t]{4}{*}{$\begin{array}{l}\text { Security and convenience } \\
(\mathrm{x} 2)\end{array}$} & $\begin{array}{l}\text { 28. Tourism attractions should have sufficient public facilities, } \\
\text { such as automated teller machines (ATM), restrooms, and } \\
\text { public phones. }\end{array}$ & 0.817 & 0.705 \\
\hline & 18. Phuket's security system should cover the entire city. & 0.873 & 0.788 \\
\hline & $\begin{array}{l}\text { 26. Phuket should have enough electricity posts to decrease the } \\
\text { number of crimes. }\end{array}$ & 0.873 & 0.788 \\
\hline & $\begin{array}{l}\text { 19. Government agencies should increase security } \\
\text { infrastructure, such as closed circuit television (CCTV) } \\
\text { cameras, around tourism attractions and residential areas. }\end{array}$ & 0.918 & 0.484 \\
\hline Cultural tourism & $\begin{array}{l}\text { 22. Tourism-related agencies should determine the seasonal } \\
\text { tourism festivals. }\end{array}$ & 0.886 & 0.541 \\
\hline \multirow{3}{*}{ Management (X3) } & 21. Local cultural tourism should be supported and promoted. & 0.896 & 0.882 \\
\hline & 29. Travelling to Phuket is convenient. & 0.896 & 0.882 \\
\hline & $\begin{array}{l}\text { 12. Government agencies should provide guidelines on } \\
\text { environmental and natural resources conservation to local } \\
\text { residents and businesses. }\end{array}$ & 0.752 & 0.756 \\
\hline \multirow{4}{*}{$\begin{array}{l}\text { Environmental and natural } \\
\text { resources conservation }(\mathrm{X} 4)\end{array}$} & $\begin{array}{l}\text { 14. Both central and local government agencies should focus } \\
\text { more on the community and help it protect and sustain natural } \\
\text { resources. }\end{array}$ & 0.533 & 0.585 \\
\hline & 10. Local residents should help protect natural resources. & 0.828 & 0.719 \\
\hline & $\begin{array}{l}\text { 8. Government agencies should heavily prosecute those who } \\
\text { destroy natural resources. }\end{array}$ & 0.726 & 0.564 \\
\hline & $\begin{array}{l}\text { 9. Government agencies should strictly enforce environmental } \\
\text { and conservation laws. }\end{array}$ & 0.564 & 0.499 \\
\hline \multirow{4}{*}{ Public facilities (X5) } & $\begin{array}{l}\text { 7. Tourist areas should have an adequate supply of restrooms, } \\
\text { and more attention should be paid to public hygiene. }\end{array}$ & 0.712 & 0.692 \\
\hline & $\begin{array}{l}\text { 5. Government agencies should regulate public transportation } \\
\text { so that tourists and residents are not exploited. }\end{array}$ & 0.671 & 0.476 \\
\hline & $\begin{array}{l}\text { 11. Directional signs should be clear and easy to see inform a } \\
\text { tourist's perspective. }\end{array}$ & 0.611 & 0.425 \\
\hline & $\begin{array}{l}\text { 30. The infrastructure system should include tourism } \\
\text { attractions. }\end{array}$ & 0.886 & 0.541 \\
\hline
\end{tabular}


27. Tourism attractions should be clean and have a sufficient supply of trashcans.

Waste management (X6)

Mass transportation system and traffic $(\mathrm{X} 7)$
13. Local government agencies should have better waste management.

2. Government agencies should expand the traffic lanes on main roads.

6. Tourism attractions should have an adequate supply of parking lots.

3. The city's transportation system should be improved, especially around tourism attractions.

4. A mass transport system, such as air-conditioned buses or a sky train, should be constructed in Phuket.

1. Phuket's current transportation system is good enough.
0.918

0.853

0.624

0.732

0.615

0.703

0.668

0.725

0.508

0.604

Based on the data analysis, the researchers grouped the factors affecting guidelines for tourism promotion in Phuket into 7 factors with 30 variables.

Factor 1 Necessities for daily life (X1): The percentage of variance was 15.508.

Factor 2 Security and convenience (X2): The percentage of variance was 13.774 .

Factor 3 Cultural tourism management (X3): The percentage of variance was 12.238.

Factor 4 Environmental and natural resources conservation (X4): The percentage of variance was 9.932.

Factor 5 Public facilities (X5): The percentage of variance was 9.037 .

Factor 6 Waste management (X6): The percentage of variance was 7.845 .

Factor 7 Transportation system and traffic (X7): The percentage of variance was 7.699.

According to these 7 factors, the reliability of the instrument (Cronbach's Alpha) was 0.9378, and the appropriate measure of data (Kaiser-Meyer-Olkin [KMO]) was 0.909. A high KMO (1) shows that the factor analysis fits the data (Kunlaya, 2006). In addition, the total variance explained was a percentage of 76.003, indicating that it appropriate for the use of factor analysis because it was higher than 60 percent (Suchat, 2005). After analyzing 30 variables, factor loading was used to extract 7 important factors as a tool to group the variables. The variables were grouped based on their relationship to the factor loading.

\subsection{Policy Guidelines for Tourism Development in Phuket}

To study the policy guidelines for tourism development and management in Phuket, the researchers collected data from the focus group discussion. The researchers invited eight tourists, government officers, business owners, and experts in business administration, management, and tourism management to discuss and identify such policy guidelines.

\subsubsection{Guidelines to Solve the High Cost of living}

The study found that travel costs in Phuket are quite high, particularly accommodations costs in tourist areas. Business owners stated that they have to pay taxes to both central and local government agencies, creating a major cause of high living and commodities costs. Therefore, government agencies should revise their taxation policies and focus on the problem of double taxation. In addition, the government also must address transportation costs. Taxi drivers in Phuket often overcharged tourists. Another problem is the high prices of food and consumable goods in tourist areas. These problems have grown in Phuket for a long time, so the government should pay serious attention to them and develop action plans to solve them.

\subsubsection{Guidelines to Solve Security Problems}

A CCTV system is highly important for tourism attractions to ensure the safety of tourists and pursue offenders, so government agencies should increase the number of CCTV cameras at important spots around Phuket. In addition, government agencies should encourage the local community and private sector to participate in security. Drug use and crime by illegal laborers were also identified as social problems needing government attention. Assigning government officers to high-risk areas to share knowledge and empower residents could decrease these problems. 


\subsubsection{Development of Cultural Tourism}

Tourists pay high attention to cultural attractions. Increasing cultural tourism requires 1) easy-to-follow routes, 2) enough restrooms, 3) clear directional signs, and 4) reasonable prices. The Sino-Portuguese buildings are a highlight attraction in Phuket; therefore, stakeholders should establish policies to preserve this unique, historical attraction. In addition, the collocation of environmental and cultural attractions benefits both residents and tourists.

\subsubsection{Environmental and Natural Resources Conservation}

Phuket faces many environmental problems, particularly the destruction of natural resources, such as turning the mangrove area into a marina. To solve these problems, the development of infrastructure and tourism services must be restricted, strongly controlled, and based on environmental and natural resource conservation. In addition, tourism resources should be managed to prevent pollution. Stakeholders, including residents, business owners, tourists, and government officials, need to cooperate to protect the environment and natural resources.

\subsubsection{Development of Public Facilities}

Public facilities, especially the transportation system, were identified as important factors in the development of tourism in Phuket, but they present many problems. For example, tourist areas have few restrooms, and tourists have to pay to use the existing ones. In addition, officials were also concerned with water supply management, especially in the high season. The transportation system needs to be improved, especially the main roads. Both central and local government agencies need to address these problems to make Phuket into a high-class tourism destination.

\subsubsection{Waste Management}

In addition to increasing the waste management capacity, government agencies need to issue and promote guidelines for tourists to take part in conserving natural resources. Local government agencies should position notice signs about conservation at tourism attractions and promote awareness of recycling among residents. Agencies need to provide education about the value of recycling and to encourage reusing objects.

\subsubsection{Development of the Transportation System}

Development of the transportation system is critical for Phuket to improve the province's economy and tourism. The government should improve the transportation network, especially the main and secondary roads, for example, by increasing the number of traffic lanes, improving traffic management, constructing new roads to support the city plan, and matching infrastructure and public utilities with user demand. Phuket's local government needs to solve this issue to compete as a high-class tourism destination.

In addition to these guidelines, participants emphasized that stakeholder participation is key to solving problems. Regulations must also be revised to implement these guidelines in tourist areas.

\section{Discussion and Conclusions}

When issuing tourism development policies, policy-makers need to understand the nature of local tourism and the role of participation in policy-making. In addition, they should study the results of previous tourism policies and know how to apply policy practically (Bramwell \& Meyer, 2007; Stevenson, Airey, \& Miller, 2008; Liu \& Wall, 2003). Policy-makers should also embrace economic, social, and environmental tools to boost the development of local tourism (Panayotou, 1994; Collins, 1999; Palmer \& Riera, 2003).

Phuket has long had a high cost of living. Double taxation is a major cause of this problem. As Mutti and Grubert (2004) discuss, tax rates play an important role in business and can encourage investment in an area. The government should lower the tax rate to stimulate investment and buying to grow the economy. The government also needs to address the cost of living, because it directly affects residents and tourists in Thailand. In addition, government agencies such as the police and Office of Consumer Protection should prosecute more vigorously business owners who overprice goods and services.

The study found that traffic and transportation systems are important to the development of sustainable tourism. Stakeholders in tourism policy should focus on these issues. Tourism resources are essential but need to be developed sustainably, particularly the transportation system, including roads, public transit, and ports (Witbreuk, 2000). To support the growth of tourism, Phuket needs to develop a mass transportation system, such as a sky train or subway, to solve the growing traffic jams, especially if it does not increase the number of traffic lanes or build new roads.

In cultural tourism management, it is widely known that tourists are interested in local culture, products, and 
lifestyles, which can be developed as tourism products (Cohen, 1996). Local products sold to tourists must be quality and reasonably priced. Tosun (2001) studied products sold to tourists in Turkey and found that the standard and quality of handicraft skills are essential, as is a logo designed to display products' identity and quality. In addition, conservation of traditional arts, such as the Sino-Portuguese buildings in the old town of Phuket, is important. These buildings are a central tourist attention. Panya (2011) stated that architecture reflects the society, culture, and lives of different generations. The unique Sino-Portuguese architectural style flourished along the Malaya peninsula, including in Penang and Singapore, and remains an important educational resource for a multicultural society interested in local societies, economies, politics, beliefs, and arts.

Security policies and infrastructure are also critical. If the installation of CCTV cameras around Phuket is completed, they can be used to monitor the city and save the lives and property of residents and tourists. In addition, officers need to take arresting offenders seriously. From interviewing foreign visitors, some revealed that they do not fear breaking some laws, such as traffic laws, for which the punishment is not heavy, because they believe that such violations can be resolved with money; as they said, "Money is God." Moreover, the problem of illegal laborers affects the safety of lives and property in Phuket. Illegal labor needs to be solved, because it both positively and negatively affects tourism. A survey conducted from October 2010 to March 2012 found that many business owners resort to using illegal laborers, because Thai labor is difficult to recruit, especially in construction, cleaning services, restaurants, and convenience stores, all of which are involved in tourism. Lui and Wall (2006) explained that, to solve labor shortages, human resources planning is essential, especially the development of a local workforce and adequate compensation. In addition, enforcement of labor and immigration laws is important. Noorbakhsh and Paloni (2001) explain that governments need to establish policies that encourage workers to perform well and train workers in skills that best suit businesses. In addition, the government must seriously consider labor costs, because investors consider it, along with the number of laborers.

Hunter (1997) asserts that people and nature can live together if conservation, environmental, and sustainable tourism policies appropriately allocate resources and manage the interaction between man and nature. Connell, Page, and Bentley (2009) studied sustainable tourism in New Zealand and found that the government must manage tourism properly and not affect nature. The government should issue national policies to support local communities and educate them about the impact of the increasing number of tourists. In addition, policies should link and balance the national tourism development plan and tourism activities. Bramwell and Lane (2002) also explained that the success of sustainable tourism management depends on appropriate planning and management in all aspects of development. In addition, the infrastructure and environment must be managed to fit the demand of the tourists.

The study found that Phuket's waste management system still presents problems. The increasing population and number of tourists produce large amounts of waste that the government cannot manage well. This problem directly affects the city's image, tourism, and the health of residents. Castellani and Sala (2010) demonstrate that the development of sustainable tourism reduces negative environmental impacts. Local government agencies in Phuket should develop policies and a practical plan to solve the problem of waste management. Leiper (1997) identified three components of good waste management of tourism attractions: 1) budget allocation, 2) technical management, and 3) integrated management.

The development of public services and infrastructure, such as roads, electricity, water supply, and telephone and Internet service, is crucial for the growth of tourism. Anwar (2006) explained that the construction of transportation and communications infrastructure add convenience to local areas. This study found that Phuket needs to accelerate the development of public services, especially transportation, to facilitate the travel of tourists to attractions. In addition, the availability of public restrooms is important. Local governments and relevant agencies need to collaborate to construct more restrooms.

Phuket faces traffic jams in both the city and tourist areas, especially from 7:30 a.m. to 9 a.m. and 3:30 p.m. to 5:30 p.m. because of several reasons. First, the traffic system is broken, and the public transport system serving residents and tourists is of low quality, negatively impacting tourism. Victor (1992) studied tourism on the Island of Bermuda (Bermuda) and found that traffic congestion and a lack of new roads led to conflicts between residential and tourist drivers and adversely affected the country's tourism image. To solve this problem, relevant agencies should add traffic lanes or build new roads in the city and near tourism attractions. The current system needs to be improved to solve the traffic jams. Parking lots should be built at tourism attractions to serve Phuket's many visitors. In addition, the development of a public transportation system, such as buses, a sky train, or subway, is necessary to reduce traffic problems. Huiqin and Linchun (2011) discussed that both tourists and residents would use a high-speed railway, a system that would solve Phuket's problems well. 


\section{Recommendations}

This research focuses on some important problems in Phuket, and the results can serve as guidelines for the government and agencies involved in tourism to develop policies for tourism management. Before formulating any guidelines or development plans, it is necessary to develop a local consensus and involve residents in every step of planning. Future research should study the results of existing guidelines for tourism development and determine improved guidelines.

\section{References}

Anwar, S. (2006). Provision of public infrastructure, foreign investment and welfare in the presence of specialisation-based external economies. Economic Modelling, 50(2), 307-322.

Bramwell, B., \& Lane, B. (2002). Collaboration and partnerships in tourism planning. In B. Bramwell, \& B. Lane (Eds.), Tourism collaboration and partnerships: Politics, practice and sustainability (pp. 1-19). Clevedon: Channel View Publications.

Bramwell, B., \& Meyer, D. (2007). Power and tourism policy relations in transition. Annuals of Tourism Research, 34(3), 766-788. http://dx.doi.org/10.1016/j.annals.2007.03.009

Castellani, V., \& Sala, S. (2010). Sustainable performance index for tourism policy development. Tourism Management, 31(6), 871-880. http://dx.doi.org/10.1016/j.tourman.2009.10.001

Charn, W. (2009). Background of tourism in Phuket. Retrieved from http://www.khuncharn.com/phukettravelstory.htm

Cohen, E. (1996). Hunter-gatherer tourism in Thailand. In R. Butler, \& T. Hinch (Eds.), Tourism and indigenous peoples (pp. 227-254). High Holborn: International Thomson Business Press.

Collins, A. (1999). Tourism development and natural capital. Annals of Tourism Research, 26(1), 98-109. http://dx.doi.org/10.1016/S0160-7383(98)00059-0

Connell, J., Page, S., \& Bentley, T. (2009). Towards sustainable tourism planning in New Zealand: Monitoring local government planning under the Resource Management Act. Tourism Management, 30(6), 867-877. http://dx.doi.org/10.1016/j.tourman.2008.12.001

Huiqin, L., \& Linchun, H. (2011). Evaluation on sustainable development of scenic zone based on tourism ecological footprint: Case study of Yellow Crane Tower in Hubei Province, China. Energy Procedia, 5(1), 145-151. http://dx.doi.org/10.1016/j.egypro.2011.03.026

Hunter, C. (1997). Sustainable tourism as an adaptive paradigm. Annals of Tourism Research, 24(4), 850-867. http://dx.doi.org/10.1016/S0160-7383(97)00036-4

Kunlaya, V. (2006). Advanced statistical analysis by the SPSS for Window (5th ed.). Bangkok: Thammasarn.

Leiper, N. (1997). The waste of tourism. Annals of Tourism Research, 24(3), 736-739. http://dx.doi.org/10.1016/S0160-7383(97)82461-9

Liu, A., \& Wall, G. (2003). Human resources development for tourism in a peripheral island: Hainan, China. In S. Gossling (Ed.), Tourism development in tropical islands: Political ecology perspectives (pp. 222-236). Sweden: Edward Elgar Publishing.

Ministry of Tourism and Sports. (2010). Tourism situation in 2009. Retrieved from http://www.thaipr.net

Mutti, J., \& Grubert, H. (2004). Empirical asymmetries in foreign direct investment and Taxation. Journal of International Economics, 62(2), 337-358. http://dx.doi.org/10.1016/S0022-1996(03)00016-3

Noorbakhsh, F., \& Paloni, A. (2001). Human capital and FDI inflows in developing countries: New empirical evidence. Journal of World Development, 29(9), 1539-1610.

Palmer, T., \& Riera, A. (2003). Tourism and environment taxes. With special reference to the Balearic ecotax. Tourism Management, 24(6), 665-674. http://dx.doi.org/10.1016/S0261-5177(03)00046-3

Panayotou, T. (1994). Economic instruments for natural resources management in less developed countries. In A. Markandya (Ed.), Policies for sustainable development: Four essays (pp. 205-268). FAO Economic and Social Development Paper 121. FAO, Rome.

Panya, T. (2011). Blending architecture of the straits and the Chinese society on Malaya peninsula in the late $19^{\text {th }}$ century to the early $20^{\text {th }}$ century. Asian Review, 31(1), 84-113.

Phuket Directory. (2011). Phuket directory. Retrieved from 
http://www.phuketdirection.com/phuket-directory-category.php?biz=6

Phuket Provincial Administrative Organization. (2010). Phuket information. Retrieved form http://www.phuketcity.org/phuketcity_en/index.php

Piboon, U. (2009). Economic and tourism policies in Phuket. Retrieved from http://information.phuketindex.com/society/people/134-2009-02-05-11-10-22.html

Promsaka Na Sakolnakorn, T., \& Naipinit, A. (2011). The problem and threat in the management of tourism sustainability in Phuket. International Journal of Management \& Information Systems, 15(2), 111-116.

Stevenson, N., Airey, D., \& Miller, G. (2008). Tourism policy making: The policymakers' perspectives. Annals of Tourism Research, 35(3), 732-750. http://dx.doi.org/10.1016/j.annals.2008.05.002

Suchart, P. (2005). Analysis of Multiple variables for social sciences research and behavior sciences research (5th ed.). Bangkok: Samlada.

Szivas, E., Riley, M., \& Airey, D. (2003). Labor mobility into tourism: Attraction and satisfaction. Annals of Tourism Research, 30(1), 64-76. http://dx.doi.org/10.1016/S0160-7383(02)00036-1

Tosun, C. (2001). Challenges of sustainable tourism development in the developing world: The case of Turkey. Tourism Management, 22(3), 289-303. http://dx.doi.org/10.1016/S0261-5177(00)00060-1

Victor, B. T. (1992). Land transportation and tourism in Bermuda. Tourism Management, 13(4), 395-405. http://dx.doi.org/10.1016/0261-5177(92)90007-T

Witbreuk, M. (2000). The effectiveness of cooperation: Regional transport systems as common pool resources. Paper presented at the 8 th IASCP Conference, Bloomington, Indiana.

Yamane, T. (1973). Statistics: An Introductory Analysis (3rd ed.). Newyork: Harper and Row Publication.

\section{Copyrights}

Copyright for this article is retained by the author(s), with first publication rights granted to the journal.

This is an open-access article distributed under the terms and conditions of the Creative Commons Attribution license (http://creativecommons.org/licenses/by/3.0/). 